\title{
Silvopasture: a sustainable livestock production system
}

\author{
Shibu Jose $\cdot$ Jeanne Dollinger
}

Received: 4 February 2019/Accepted: 4 February 2019/Published online: 7 February 2019

(C) Springer Nature B.V. 2019

\begin{abstract}
Silvopasture, as an integrated land use practice that combines trees, forage and livestock, has been in existence for millennia. There are many variants of this land use in both the temperate and tropical regions of the world practiced at small and large scales. Modern silvopasture; however, is not just a new name for an old practice. It is rooted in sound ecological principles and demands skills in managing complexity. Scientific evidence of the ecological and economic benefits of silvopasture has been accumulating rapidly over the last few years and hence the objective of this thematic issue was to bring together a collection of original research and review articles that dealt with these different dimensions. There are 28 articles included in this thematic issue categorized into four groups based on their primary focus, (1) forage production and quality (2) livestock performance (3) environmental benefits, and (4) challenges in designing and developing silvopasture. The information presented has deepened our understanding of some of the biophysical and socioeconomic dimensions of
\end{abstract}

S. Jose $(\bowtie)$

College of Agriculture, Food and Natural Resources,

University of Missouri, 2-44 Agriculture Building,

Columbia, MO 65211, USA

e-mail: joses@missouri.edu

J. Dollinger

INRA UMR EMMAH, Domaine Saint Paul,

84000 Avignon, France

e-mail: jeanne.dollinger@inra.fr silvopastoral systems; however, it also has revealed some of the research gaps. Addressing these research gaps will help improve not only the economic and environmental sustainability of these systems, but their social acceptability as well.

Keywords Forages - Animal nutrition - Cattle production · Forest $\cdot$ Pasture

\section{Introduction}

Agriculture is facing intense pressure globally for increasing productivity with greater environmental accountability. There is growing body of evidence that agroforestry, when properly designed and managed, can provide the environmental accountability being demanded by the public while enhancing production. Silvopasture, an agroforestry system that combines trees and livestock with forage to form a carefully designed system, has gained popularity in recent years as an environmentally friendly alternative land use system that is economically viable (Jose et al. 2019). The wild expression of this system is the savanna, which is a mid-successional system of grasslands interspersed with trees and shrubs (Freeman and Jose 2009).

Animal grazing in savannas, forests, and woodlands is an old form of silvopasture in many parts of the world. For example, the dehesas (Spain) and montados 
(Portugal) are some of the oldest examples of agroforestry practices that include scattered oak trees with an herbaceous understory. However, modern silvopasture is not just a new name for a millennia-old practice. As Garrett (2009) states, silvopasture management, like other forms of agroforestry, is based on our thinking in both spatial and temporal domains, and it demands skills in managing rather than reducing complexity. An understanding of hierarchical relationships within ecosystems and recognition that defined ecosystem-boundaries exist primarily for managerial convenience are essential to this concept (Garrett and Buck 1997). Thus, silvopasture refers to combining trees, forage plants, and livestock in an integrated and intensively managed system.

There has been a tremendous growth in the number of publications on silvopasture in the recent past. Most studies have shown an overall increase in system productivity, including greater productivity of animals. However, comprehensive reviews and synthesis have been rare. The objective of this special issue is to bring together a collection of original research and review articles that deal with the different aspects of silvopasture from both the temperate and tropical regions of the world. We categorized the 28 articles included in this thematic issue into four groups based on their primary focus, (1) forage production and quality (2) livestock performance (3) environmental benefits, and (4) challenges in designing and developing silvopasture. These articles are briefly introduced in the following sections.

\section{Forage production and quality}

The productivity and quality of the forages grown in silvopasture determine the cattle carrying capacity of the paddocks and the economic viability of the systems. The presence of trees modify light and water availability and might generate root competition for nutrients. Therefore, depending on the system design and forage choices, the presence of trees could potentially influence the productivity and nutritional quality of the forages.

Pang et al. (2019a) tested the effect of moderate (45\% sunlight) and dense shade (20\% sunlight) on forage yields of 43 species. They grew the forages in pots, which prevented root competition from other species and supplied the forages with adequate water and nutrient supply. Their results show that the annual forage yields were higher under moderate shade for all 43 species than under full sun and even higher under dense shade for 31 of them. They noticed that $\mathrm{C}_{3}$ grasses were more resilient to shade than $\mathrm{C}_{4}$ grasses. They concluded that most grass and legume forages could perform equally well in agroforestry compared to open-pasture systems as long as the root competition with other species remained minimal. In a companion study, Pang et al. (2019b) evaluated the effect of moderate and dense shade on the quality and nutritive value of 22 forages including 16 grass species and 6 legumes. The results of this study showed that all forages had equivalent crude protein content when grown under moderate shade than in the full sun and 18 out of the 22 had also equivalent crude protein contents when grown under dense shade. The relative feed value was maintained under moderate shade for 15 forages and under dense shade for 14 of them. They concluded that most grass and legume forages would have quality equivalent or even greater when grown in silvopasture compared to open-pasture.

Scaling up to field scale, Pezzopane et al. (2019) studied the effect of light restriction on forage productivity in integrated corn-livestock and grasslivestock systems with and without trees in Brazil. They measured yields and nutritive properties of the forages, corn and Piata-grass, at different distances from the eucalyptus tree lines. They also monitored photosynthetically active radiation at the locations where the forages were sampled. Their results showed that the position relative to the tree line affected the corn productivity and characteristics especially during the periods of drought. They noticed that Piata-grass yields increased with the distance from the tree line because of decreasing shade, but were still greater in the system with trees than in the one without trees. The nutritive value of both forages benefited from moderate shade and were improved in systems with trees at a distance of $7.5 \mathrm{~m}$ from the tree lines compared to the same systems at $1.5 \mathrm{~m}$ or $11.5 \mathrm{~m}$ from to the trees or compared to the systems without trees.

In a contrasted pedo-climatic context, Orefice et al. (2019) evaluated forage production and quality, and financial outcomes of an early successional northern hardwood forest in New York, USA, converted to silvopasture, open-pasture and thinned forest systems, respectively. Their results showed that the production of forage biomass in the silvopasture system was 
lower than that of open-pasture in the first year of the study, but was similar during the second year. In addition, the analysis of the forage quality revealed that the crude protein content was higher in the silvopasture forage while the acid and neutral detergent fiber concentration equaled that of open-pasture forage. The authors concluded that the presence of trees increased the nutritive value of the forage without decreasing its digestibility. The analysis of the financial indicators showed that regardless of the initial timber harvesting cost, silvopasture outperformed open-pasture in terms of internal rate of return and net present value. In Central Minnesota, Ford et al. (2019) compared the forage production and nutritive quality and the livestock performance between a conventional open-pasture, a silvopasture and a woodland system for 3 farms with contrasted soil properties. Four calf pairs rotationally grazed the 2-hectare paddocks and they measured the forage quantity and quality before each grazing cycle. The results revealed that the forage productivity was the highest in the open-pasture systems and the lowest in the woodlands. However, when drought conditions were recorded, silvopastoral systems outperformed the other in terms of forage productivity. The forage quality varied with seasons and sites, but the system's effect remained minimal. In addition, the livestock productivity were comparable between the systems. In the Appalachia, Fannon et al. (2019) compared the performance of 8-year-old honeylocust silvopasture, black walnut silvopasture and open-pasture in terms of forage composition, yield, nutritive value as well as hairsheep production. Their results showed that the pre-graze forage biomass was always higher in the open-pasture than in the honeylocust or black walnut silvopastoral systems. Moreover, forage production over the summer was greater in the honeylocust than in the black walnut silvopasture. Post-grazed biomass followed a similar trend. The forage quality remained equivalent in all systems along the experiment. Therefore, the hairsheep carcass attributes monitored were un-affected by the treatments.

Differing from traditional silvopastoral systems, Clavijo et al. (2019) explored the potential benefits of sowing perennial cool season grasses in the understory of commercial poplar plantations of the Paran River delta in Argentina. They compared forage biomass of non-sown plots with that of plots sown with three grasses. They observed that the forage production difference was minimal in summer, but increased throughout fall and peaked in the winter. They concluded that the cattle carrying capacity of the sown poplar stands could increase from zero to 0.2 cows per hectare in autumn and further by 10 times in winter.

Forest understory forages present great spatial and seasonal variability and might not always be of good enough quality for cattle grazing. Therefore, Mendarte et al. (2019) developed and tested a methodology based on Visible-Near infrared Spectroscopy (VISNIRS) to rapidly quantify the attribute of understory shrubs such as Rubus sp. and Ulex gallii as browse in Pinus radiata stands. They evaluated the seasonal and spatial variability of the browse quality and compared it to their estimations from VIS-NIRS. Their method proved to be very accurate and rapid in predicting the nutritive quality and could therefore help make rapid management decisions in cattle grazing management. The method requires; however, a large calibration dataset.

\section{Livestock performance}

The productivity of livestock in silvopastoral systems depends on the quality and yield of the forages produced throughout the year. In arid and semi-arid areas or other lands submitted to extended periods of drought, understory forage production alone is not enough to sustain an economically viable livestock production operation. Silvopasture offers alternative animal feed sources such as tree leaves or pods. These tree by-products used for animal feed complementation is a key to sustain livestock and poultry productions especially in areas exposed to severe drought periods, but also in temperate agroforestry.

Pent and Fike (2019) compared lamb productivity between two silvopastoral systems and an openpasture and evaluated the possibility of using honey locust pods as feed supplementation in temperate agroforestry. They established the silvopasture systems by thinning 17-year-old honey locust and black walnut stands. The lambs were initially naïve to honey locust pods. To acquire the taste for pods, the lambs grazing in the honey locust silvopasture were supplemented with pods mixed with wheat grain. The lambs grazing the other systems were supplemented with wheat grain only. Their results showed that the lamb 
productivity was equivalent among the three systems. The lambs started eating honey locust pods from the ground only at the 4th week of the study. The authors concluded that they must acquire a taste for the pods before voluntarily consuming them.

Ascencio-Rojas et al. (2019) characterized the chemical and cow in vivo rumen degradation of six trees and shrubs species from Mexico including Diphysa robinioides, Gliricidia sepium, Erythrina americana, Bursera simaruba, Bambusa vulgaris and Zanthoxylum riedelianum. Their results revealed that the dry matter and chemical composition varied with trees and seasons. Legume fodder had a higher effective degradability and crude protein content than non-legume ones. In general, the trees studied exhibited improved chemical composition than most common forages of the Mexican humid tropics. Some fodder trees such as G. sepium had uniform characteristics throughout the year, which would help maintain an adequate nutrient supplementation of cows especially during the critical dry season. Melesse et al. (2019) analyzed the nutrient composition, nutritional factors and the in vitro digestibility of foliage from the 12 tropical trees Sesbania sesban, Moringa stenopetala, Moringa oleifera, Acacia abysinica, Leucaena leucocephala, Azadirachta indica, Cajanus cajan, Millettia ferruginea, Acacia nilotica, Prosopis juliflora and Chamaecytisus palmensis. Beyond the aim of evaluating their potential use in cow diets, the authors investigated the mitigation of enteric $\mathrm{CH}_{4}$ emission by using the Hohenheim in vitro gas production technique. The authors stated that leaves of M. stenopetala, M. oleifera, M. ferruginea, A. abysinica and $L$. leucocephala can be used as alternative protein sources for supplementing low quality tropical forages. Leaves of $S$. sesban and $L$. leucocephala could be used as alternative calcium and magnesium sources while those of Moringa species and M. ferruginea as sources of phosphorous. Leaves of A. nilotica, P. juliflora and C. cajan as well as pods of $M$. ferruginea were identified as potential candidates for mitigating $\mathrm{CH}_{4}$ production. The authors concluded that the combinations of these plant materials with grasses or agro-industrial byproducts could be an interesting future research area to concurrently reduce ruminal methane formation while enhancing the ruminants' supply with protein sources.

Sebola et al. (2019) characterized the chemical composition and digestibility of $M$. oleifera based diets for feeding three chicken strains in South Africa. They collected $M$. oleifera leaves at two maturity stages and analyzed their protein, carbohydrate, amino-acid contents and phenolic compounds. The nutritive value of leaves mixed with a commercial finisher diet was tested when the chicken were 90-days-old by subtracting nutrient in feed by nutrient in feces. The chemical analyses revealed that the crude protein as well as the calcium and phosphorus content was greater in tender than in mature leaves. The phenolic and iron contents were higher in mature leaves. From the chemical analyses and digestibility tests the authors concluded that including M. oleifera leaves in the diet of the three studied strains could improve their productivity in these extensively-reared chickens.

Tree byproducts sometimes contain high level of tannins and phenolic compounds that reduce their digestibility. Pre-treatments of some fodder tree products could counteract this issue. Kewan et al. (2019) evaluated the effect of replacing the traditional clover hay diet with Moringa stalks treated with fungi or yeast in lambs. The authors performed in vivo digestibility test using metabolic cages. The complementary chemical composition analyses showed that the crude protein and nitrogen free extract digestibility differed between the diets while the total digestible nutrient did not. The average daily gain of the lambs fed with the clover hay, fungi-treated Moringa and yeast-treated Moringa diets were 173, 139 and $146 \mathrm{~g} / \mathrm{head} / \mathrm{day}$, respectively. The yeast-treated Moringa diet recorded the highest economical feed efficiency. The authors concluded that treatment of Moringa stalks with $S$. cerevisiae for 21 days in a solid-state fermentation system improves its nutritive value and is more suitable for sheep feeding rations. Daily feed cost can be lowered by $24 \%$ for the Moringa diets compared to clover hay.

Growing livestock in commercial plantations provide several benefits such as extra fertilization or weeding and diversify the income. Dávila-Solarte et al. (2019) tested the economic viability of growing lamb in coffee plantations. Their results showed that the return on investment was $113 \%$ and $117 \%$ for sheep grazing in coffee plantations with and without food supplementation, respectively compared to the $130 \%$ of the traditional coffee plantation. The authors concluded that growing lambs in coffee plantations is 
economically viable and offers environmental and agronomic benefits.

\section{Environmental benefits}

The environmental benefits of silvopasture compared to open-pasture systems are multiple and range from enhanced carbon storage to enriched biodiversity. These environmental aspects, especially the carbon storage potential of the different compartments of silvopasture, are increasingly valued in the present context of climate change. Several of the papers included in this section focus primarily on the carbon sequestration potential. Estimates of carbon stocks in the soil, grass and tree compartments of various silvopastoral systems are important in designing climate-smart agriculture.

Varsha et al. (2019) compared the forage productivity and quality as well as the carbon storage of the fodder grass hybrid Napier, the fodder tree Mulberry and the fodder herbaceous legume Stylosanthus grown in monocultures and in mixed systems with combinations of two of these fodders or the three of them. Hybrid Napier monoculture, the current popular system among farmers of southern India, yielded the highest forage dry matter, but the fodder quality and carbon fixation were the lowest. Mulberry monoculture system excelled in carbon fixation, but the forage yields were significantly lower. Considering the fodder crude protein yields and carbon storage capacity, the intensive silvopasture composed of hybrid Napier and Mulberry trees was the most promising system meeting both farmer's needs and environmental accountability expectations.

In a contrasted pedo-climatic context, López-Santiago et al. (2019) compared the carbon storage of a Leucaena leucocephala and Panicum maximum silvopasture system to those of a deciduous tropical forest and a grass monoculture in Mexico. They estimated the aboveground and root biomass with allometric models and measured the soil organic carbon down to $30 \mathrm{~cm}$ depth. According to these authors, the forest and silvopasture sites recorded higher aboveground biomass than the prairie and the greatest root biomass was estimated for the silvopasture treatment. Compared to the two other systems, the forest had the highest soil organic carbon (SOC) fraction at all the investigated depths. Overall, the global carbon storage was the lowest for the grass monoculture and highest for the silvopastoral system. Also in Mexico, Aryal et al. (2019) compared the carbon storage between a multi-tree-based silvopastoral system and an open-pasture. They estimated the tree biomass and root biomass using allometric models and measured the grass biomass and SOC down to $15 \mathrm{~cm}$. Their results showed that the carbon stored in the herbaceous compartment was greater in the silvopasture and the SOC followed a similar trend. Overall, they also observed a greater carbon storage potential for the silvopastoral system compared to the open-pasture.

Cárdenas et al. (2019) evaluated the ecological structure and carbon storage of traditional silvopastoral systems in Nicaragua. They characterized the plant richness and diversity, measured SOC down to $1 \mathrm{~m}$ depths and estimated the above and belowground biomasses using allometric models. They found that the studied shrub land and secondary forest had higher species diversity and richness than the degraded pasture, the farmed secondary forest and the low and high tree density pastures. They recorded the greatest carbon storage in the farmed forest and in the high tree density pasture followed by the shrub land and low tree density pasture. They concluded that SOC was the major carbon storage compartment in all systems. SOC was equivalent in all systems down to $10 \mathrm{~cm}$ depth; then was greatly contrasted with greatest SOC content recorded in the secondary forest and the lowest for the degraded pasture. The authors emphasized the need for SOC measurement down to $1 \mathrm{~m}$ depth for better estimations of carbon storage.

The tree biomass is traditionally estimated using allometric models, which is an inexpensive nondestructive method. The calibration, accuracy and adaptability of these models for trees growing in silvopastoral systems have been the subject of several studies in the recent past, but more site and systemspecific information is needed. Within this perspective, Zianis et al. (2019) tested classical and Bayesian allometric approaches to estimate the aboveground biomass of valonian oak trees growing in Mediterranean silvopastoral systems. They compared the biomass and trees characteristics estimated by the different approaches to actual biomass of 25 oaks that were destructively sampled. Their results showed that all approaches provided accurate estimates of the global biomass, but only the Bayesian model provided 
biologically sound predictions. Comparisons to oak trees growing in closed stands indicated that opengrown oaks had much less stem biomass, but maintained larger branch biomass than forest-grown counterparts.

The presence of trees in grasslands has often been reported to influence soil biological processes, resulting in enhanced soil quality indicators. However, Gonzalez-Polo et al. (2019) presents a different story in their paper. To estimate the effect of land conversion from native grassland to pine plantations, these authors compared the soil organic matter, microbial activity and associated biogeochemical functions between both systems in a semiarid area of northwestern Patagonia. They collected soil samples along transects in an extensively grazed native grasslands and in 10-13 year-old pine stands for analysis of C, N, $\mathrm{P}$, microbial biomass and enzyme activities. They also measured $\mathrm{N}$-mineralization and litter degradation in situ. They did not observe any significant differences in soil microclimatic variables, $\mathrm{pH}$, electrical conductivity, P-Olsen, total $\mathrm{C}$ and $\mathrm{N}$ following 13 years of plantation establishment. N-mineralization varied with the seasons, but remained equivalent for both systems. Land conversion from native grasslands to pine plantations clearly affected decomposition rates of grasses with a $10 \%$ lower grass degradation rate recorded under pines. Also, soil microbial biomass and, less markedly, acid phosphatase and leucin-aminopeptidase activities decreased under pine cover. They attributed the lack of significant effects of afforestation on soil chemical and some biological properties to high degree of spatial heterogeneity, species, prior land use, soil's capacity to protect and accumulate organic matter and the relatively short nature of time since establishment of the plantation.

\section{Challenges in designing and developing silvopasture}

One of the main challenges in silvopasture is the establishment of trees in paddocks grazed by livestock. Indeed, both browsing of newly planted seedlings and debarking of well-established trees compromise their survival and growth. While analyzing the diurnal behavior of kiko goats grazing in wellestablished southern-pine silvopastoral systems in
Alabama USA, Karki et al. (2019) noticed that the animals spent about $2 \%$ of their time derbaking trees. Nicodemo and Porfírio-da-Silva (2019) reviewed the reports of bark stripping in silvopastoral systems and correlated it to the conditions for the occurrence of damage. Their study aimed to suggest management strategies that could reduce this risk. They identified several causes for bark stripping behaviors related to (1) dietary deficiency (food quantity or quality; fiber, protein, energy, mineral deficiencies); (2) social learning; (3) learning and post-ingestive feedback; (4) stress and boredom. They recommended the following strategies to minimize bark stripping: (1) providing good quality pastures, supplemented with minerals, energy and/or protein when necessary; (2) keeping adequate stocking rates; (3) following practices of good animal welfare to reduce stress; (4) promoting environmental enrichment; (5) promoting dietary diversity, including addition of tannin enriched forage in the pastures; (6) avoiding mixing naive and cattle with previous experience of bark stripping; (7) providing effective health and parasites management; and (8) selecting trees less vulnerable to animal browsing.

Zhang et al. (2019) investigated the influence of grazing timing and height on the resprouting ability of 12 oak species. They planted acorns in individual pots and simulated grazing by clipping the seedlings at different stages, heights and dates. They found that seedlings clipped 5 days after germination resprouted much more quickly and showed higher dry masses of regenerated shoots than those clipped 10 days after germination. However, the final regeneration success of the 12 oak species was not different in seedlings clipped at the two different development stages. Seedlings clipped to a higher stubble height $(3 \mathrm{~cm})$ regenerated more quickly than those clipped to a lower stubble height and had greater final regeneration success. These results demonstrated that while grazing calendar would not influence the regeneration success, grazing height would play a role in determining the establishment success. In a different context, Mekonnen et al. (2019) evaluated the survival and growth of leguminous trees introduced in mixed crop-livestock systems in Ethiopia for soil fertility improvement. Farmers from four sites taking part in a local development project, Africa RISING, were given 50 Lucerne seedlings each to plant at different location of their farm. The tree survival, growth and root collar 
diameter were monitored 9 months after planting. After this time laps, $50 \%$ of the farmers experienced total seedling loss and the survival rate was higher for backyards than open-fields. The authors related the poor seedling survival to a lack of post-planting maintenance. They observed that access to reliable water supply, fencing of planted seedlings to protect them from browsing, mulching during dry periods, a clean spot-weeding and applying organic fertilizers (manuring) significantly enhanced survival and growth of Lucerne seedlings.

Designing and maintaining productive silvopastoral systems adapted to each local context can be challenging. To address this challenge, Jose et al. (2019) proposed a key design criterion which was to optimize the use of spatial, temporal, and physical resources, by maximizing positive (facilitation) and minimizing negative (competition) interactions among system components. These complex systems are not removed from the ecological principles that guide and direct interactions among trees, forages, and livestock. Hence, these authors attempted to demonstrate how the general ecological principles common to complex natural systems could be applied in designing and managing sustainable silvopastoral systems. They discussed how (1) spatial and temporal heterogeneity can enhance system performance; (2) complementarity can be maximized with perennialism; (3) structural and functional diversity can be exploited for improved resource utilization; and (4) disturbance ecology principles can be used for sound management decisions. They concluded that analyzing silvopastoral systems in the light of these ecological principles would help improve design and management strategies.

Despite all the challenges associated with silvopasture establishment, this model of livestock production is spreading the world over. The drivers or obstacles for the development of silvopasture vary locally. Bussoni et al. (2019) analyzed the Uruguayan National General Agriculture Census data and the annual national survey of livestock database with the objective of quantifying the emerging practice of silvopasture, and identifying the diversity of patterns of production structure and resource use of these systems. Following certain criteria, they selected 1019 commercial silvopastoral systems for their study, which represented $58 \%$ of the afforested area and $9 \%$ of the livestock units. These authors identified seven strategies of integration of livestock with timber by either individual cattle farmers or by corporations. In all strategies silvopasture was producing livestock and timber at the same time which might help inform sustainability assessments as well as future private and public policies regarding expansion of silvopastoral systems.

In the US, natural resources professionals (NRPs) advise and trains landowners about the best management practices in agriculture for resources conservation. Therefore, Stutzman et al. (2019) investigated their familiarity with silvopasture as well as their learning and perception of the suitability of these systems in southern US. They conducted qualitative interviews with professionals familiar with silvopasture and used the answers to construct an online questionnaire. Over 1000 professionals over the states of Mississippi, Alabama, Florida and Georgia were surveyed using this online questionnaire with a $50 \%$ respondent rate. Their results showed that $64 \%$ of the respondents had heard of silvopasture and $54 \%$ had even participated in a silvopasture field day. NRPs were more trained in silvopasture than registered foresters and the training rate differed among states. The authors concluded that silvopasture had great potential in the southern US due to high forest coverage; however, education of professionals and advising of landowners would be needed to enhance adoption. Another obstacle to the local development of silvopasture is the lack of scientific data. Therefore, in their meta analysis of the literature dealing with Mediterranean silvopasture, Leal et al. (2019) tackled the question of how scientific research was addressing the ecological and socioeconomic dimensions of sustainable management in cork oak silvopastoral systems. They observed that most aspects of this system were studied well, but the climate change and social dimensions would require more research efforts to address the emerging challenges.

\section{Conclusion}

Silvopasture, as an integrated land use practice, has been proven to be economically and environmentally sustainable both at small and large scales. Scientific evidence from the last decade in particular has been critical in promoting the adoption of this practice worldwide. There has been a tremendous growth of 
additional scientific evidence in the last few years, which has helped bring out this thematic issue. The 28 articles presented here have clearly helped improve our understanding of some of the biophysical and socioeconomic dimensions of silvopastoral systems; however, they also helped identify some of the research gaps. Addressing these research gaps is critical so that the economic and environmental sustainability of silvopasture can be enhanced and its social acceptability can be increased.

\section{References}

Aryal DR, Gómez-González RR, Hernández-Nuriasmú R, Morales-Ruiz DE (2019) Carbon stocks and tree diversity in scattered tree silvopastoral systems in Chiapas, Mexico. Agrofor Syst. https://doi.org/10.1007/s10457-018-0310-y

Ascencio-Rojas L, Valles-de la Mora B, Castillo-Gallegos E, Ibrahim M (2019) In situ ruminal degradation and effective degradation of foliage from six tree species during dry and rainy seasons in Veracruz, Mexico. Agrofor Syst. https:// doi.org/10.1007/s10457-018-0184-z

Bussoni A, Alvarez J, Cubbage F, Ferreira G, Picasso V (2019) Diverse strategies for integration of forestry and livestock production. Agrofor Syst. https://doi.org/10.1007/s10457017-0092-7

Cárdenas A, Moliner A, Hontoria C, Ibrahim M (2019) Ecological structure and carbon storage in traditional silvopastoral systems in Nicaragua. Agrofor Syst. https://doi. org/10.1007/s10457-018-0234-6

Clavijo MP, Cornaglia PS, Batisttella A, Borodowski E (2019) Floristic enrichment of the understory increases forage production and carrying capacity of temperate silvopastoral systems. Agrofor Syst. https://doi.org/10.1007/ s10457-017-0164-8

Dávila-Solarte P, Sanginés-García L, Amezcua T, Solano L (2019) Productive performance and economic evaluation of sheep grazing on weeds in coffee plantations compared to pastures with or without supplementation. Agrofor Syst. https://doi.org/10.1007/s10457-017-0165-7

Fannon AG, Fike JH, Greiner SP, Feldhake CM, Wahlberg MA (2019) Hair sheep performance in a mid-stage deciduous Appalachian silvopasture. Agrofor Syst. https://doi.org/10. 1007/s10457-017-0154-x

Ford MM, Zamora DS, Current D, Magner J, Wyatt G, Walter WD, Vaughan S (2019) Impact of managed woodland grazing on forage quantity, quality and livestock performance: the potential for silvopasture in Central Minnesota, USA. Agrofor Syst. https://doi.org/10.1007/s10457-0170098-1

Freeman J, Jose S (2009) The role of herbicide in savanna restoration: effects of shrub reduction treatments on the understory and overstory of a longleaf pine flatwoods. For Ecol Manag 257:978-986
Garrett HE (2009) North American agroforestry. An integrated science and practice, 2nd edn. American Society of Agronomy, Madison

Garrett HE, Buck L (1997) Agroforestry practice and policy in the United States of America. For Ecol Manag 91:5-15

Gonzalez-Polo M, Bahamonde HA, Peri PL, Mazzarino MJ, Fariña C, Caballé G (2019) Soil microbial processes in a pine silvopastoral system in NW Patagonia. Agrofor Syst. https://doi.org/10.1007/s10457-018-0210-1

Jose S, Walter D, Mohan Kumar B (2019) Ecological considerations in sustainable silvopasture design and management. Agrofor Syst. https://doi.org/10.1007/s10457-0160065-2

Karki U, Karki Y, Khatri R, Tillman A (2019) Diurnal behavior and distribution patterns of Kiko wethers in southern-pine silvopastures during the cool-season grazing period. Agrofor Syst. https://doi.org/10.1007/s10457-018-0229-3

Kewan KZ, Salem FA, Salem AZM, Abdou AR, El-Sayed HM, Eisa SS, Zaki EA, Odongo NE (2019) Nutritive utilization of Moringa oleifera tree stalks treated with fungi and yeast to replace clover hay in growing lambs. Agrofor Syst. https://doi.org/10.1007/s10457-017-0158-6

Leal AI, Correia RA, Palmeirim JM, Bugalho MN (2019) Is research supporting sustainable management in a changing world? Insights from a Mediterranean silvopastoral system. Agrofor Syst. https://doi.org/10.1007/s10457-0180231-9

López-Santiago JG, Casanova-Lugo F, Villanueva-López G, Díaz-Echeverría VF, Solorio-Sánchez FJ, Martínez-Zurimendi P, Aryal DR, Chay-Canul AJ (2019) Carbon storage in a silvopastoral system compared to that in a deciduous dry forest in Michoacán, Mexico. Agrofor Syst. https://doi. org/10.1007/s10457-018-0259-x

Mekonnen K, Jogo W, Bezabih M, Mulema A, Thorne P (2019) Determinants of survival and growth of tree lucerne (Chamaecytisus palmensis) in the crop-livestock farming systems of the Ethiopian highlands. Agrofor Syst. https:// doi.org/10.1007/s10457-016-0066-1

Melesse A, Steingass H, Schollenberger M, Holstein J, Rodehutscord M (2019) Nutrient compositions and in vitro methane production profiles of leaves and whole pods of twelve tropical multipurpose tree species cultivated in Ethiopia. Agrofor Syst. https://doi.org/10.1007/s10457017-0110-9

Mendarte S, Gandariasbeitia M, Albizu I, Larregla S, Besga G (2019) Prediction of browse nutritive attributes in a Pinus radiata $\mathrm{D}$. Don silvopastoral system based on visible-near infrared spectroscopy. Agrofor Syst. https://doi.org/10. 1007/s10457-018-0192-z

Nicodemo MLF, Porfírio-da-Silva V (2019) Bark stripping by cattle in silvopastoral systems. Agrofor Syst. https://doi. org/10.1007/s10457-018-0185-y

Orefice J, Smith RG, Carroll J, Asbjornsen H, Howard T (2019) Forage productivity and profitability in newly-established open pasture, silvopasture, and thinned forest production systems. Agrofor Syst. https://doi.org/10.1007/s10457016-0052-7

Pang K, Van Sambeek JW, Lin C-H, Jose S, Garrett HE (2019a) Responses of legumes and grasses to non-, moderate, and dense shade in Missouri, USA. I. Forage yield and its 
species-level plasticity. Agrofor Syst. https://doi.org/10. 1007/s10457-017-0067-8

Pang K, Van Sambeek JW, Navarrete-Tindall NE, Lin C-H, Jose S, Garrett HE (2019b) Responses of legumes and grasses to non-, moderate, and dense shade in Missouri, USA. II. Forage quality and its species-level plasticity. Agrofor Syst. https://doi.org/10.1007/s10457-017-0068-7

Pent GJ, Fike JH (2019) Lamb productivity on stockpiled fescue in honeylocust and black walnut silvopastures. Agrofor Syst. https://doi.org/10.1007/s10457-018-0264-0

Pezzopane JRM, Bernardi ACC, Bosi C, Oliveira PPA, Marconato MH, de Faria Pedroso A, Esteves SN (2019) Forage productivity and nutritive value during pasture renovation in integrated systems. Agrofor Syst. https://doi.org/10. 1007/s10457-017-0149-7

Sebola NA, Mlambo V, Mokoboki HK (2019) Chemical characterisation of Moringa oleifera (MO) leaves and the apparent digestibility of MO leaf meal-based diets offered to three chicken strains. Agrofor Syst. https://doi.org/10. 1007/s10457-017-0074-9

Stutzman E, Barlow RJ, Morse W, Monks D, Teeter L (2019) Targeting educational needs based on natural resource professionals' familiarity, learning, and perceptions of silvopasture in the southeastern U.S. Agrofor Syst. https:// doi.org/10.1007/s10457-018-0260-4

Varsha KM, Raj AK, Kurien EK, Bastin B, Kunhamu TK, Pradeep KP (2019) High density silvopasture systems for quality forage production and carbon sequestration in humid tropics of Southern India. Agrofor Syst. https://doi. org/10.1007/s10457-016-0059-0

Zhang Y, Li J, Zhang D, Wang Z, Yi X (2019) Effects of grazed stubble height and timing of grazing on resprouting of clipped oak seedlings. Agrofor Syst. https://doi.org/10. 1007/s10457-018-0206-x

Zianis D, Pantera A, Papadopoulos A, Mosquera Losada MR (2019) Bayesian and classical biomass allometries for open grown valonian oaks (Q. ithaburensis subs. macrolepis L.) in a silvopastoral system. Agrofor Syst. https://doi.org/10. 1007/s10457-016-0060-7

Publisher's Note Springer Nature remains neutral with regard to jurisdictional claims in published maps and institutional affiliations. 